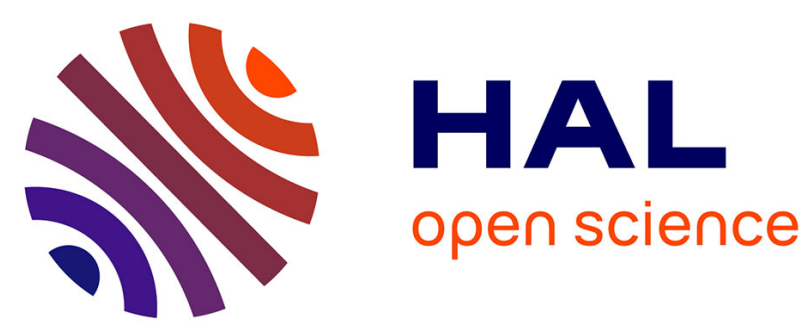

\title{
Prostate cancer and occupational whole-body vibration exposure.
}

Victoria Nadalin, Nancy Kreiger, Marie-Elise Parent, Alan Salmoni, Andrea Sass-Kortsak, Jack Siemiatycki, Margaret Sloan, James Purdham

\section{To cite this version:}

Victoria Nadalin, Nancy Kreiger, Marie-Elise Parent, Alan Salmoni, Andrea Sass-Kortsak, et al.. Prostate cancer and occupational whole-body vibration exposure.. Annals of Occupational Hygiene, 2012, 56 (8), pp.968-74. 10.1093/annhyg/mes010 . pasteur-01009268

\section{HAL Id: pasteur-01009268 https://hal-riip.archives-ouvertes.fr/pasteur-01009268}

Submitted on 17 Jun 2014

HAL is a multi-disciplinary open access archive for the deposit and dissemination of scientific research documents, whether they are published or not. The documents may come from teaching and research institutions in France or abroad, or from public or private research centers.
L'archive ouverte pluridisciplinaire HAL, est destinée au dépôt et à la diffusion de documents scientifiques de niveau recherche, publiés ou non, émanant des établissements d'enseignement et de recherche français ou étrangers, des laboratoires publics ou privés. 


\title{
Prostate Cancer and Occupational Whole-Body Vibration Exposure
}

\section{VICTORIA NADALIN ${ }^{1 *}$, NANCY KREIGER ${ }^{1,2}$, MARIE-ELISE PARENT $^{3}$, ALAN SALMONI ${ }^{4}$, ANDREA SASS-KORTSAK ${ }^{5}$, JACK SIEMIATYCKI ${ }^{6}$, MARGARET SLOAN ${ }^{1}$ and JAMES PURDHAM ${ }^{5}$}

\author{
${ }^{1}$ Research, Prevention and Cancer Control, Cancer Care Ontario, 620 University Avenue, Toronto, \\ Ontario, Canada M5G 2L7; ${ }^{2}$ Epidemiology, Dalla Lana School of Public Health, University of \\ Toronto, 155 College Street, Toronto, Ontario, Canada M5T 3M7; ${ }^{3}$ Institut Armand Frappier, Institut \\ National de la Recherche Scientifique, Universite de Quebec, 531, boulevard des Prairies, Laval, \\ Quebec, Canada H7V 1B7; ${ }^{4}$ School of Kinesiology, Faculty of Health Sciences, Western University, \\ London, Ontario, Canada N6A 5B9; ${ }^{5}$ Occupational and Environmental Health, Gage Occupational \& \\ Environmental Health Unit, 223 College St., Toronto, Ontario, Canada M5T 1R4; ${ }^{6}$ Department of \\ Social and Preventive Medicine, University of Montreal, PO Box 6128, Station Centre-ville, Montréal, \\ Quebec, Canada H3C $3 \mathrm{~J} 7$
}

Received 6 July 2011; in final form 2 February 2012; published online 26 April 2012

\begin{abstract}
Prostate cancer is common and its etiology largely unknown; therefore, it is important to explore all potential risk factors that are biologically plausible. Recent literature suggests a relationship between whole-body vibration (WBV) and prostate cancer risk. The aim of this study was to determine whether occupational WBV was a risk factor for prostate cancer. Existing data, collected on 447 incident cases and 532 population controls (or their proxies), in Montreal, Canada, were used to evaluate this question. Personal interviews collected detailed job descriptions for every job held, the tasks involved, and type of equipment used. For each job, experts assessed the intensity and daily duration of WBV exposure. Inter-rater agreement for WBV ratings was examined using the kappa statistic, with values that ranged from 0.83 to 0.94 . Logistic regression models explored the relationship between WBV exposure and prostate cancer, using various combinations of intensity, daily duration, and years of exposure. Potential confounders were also examined. Occupations with WBV exposure demonstrated an increased statistically non-significant risk [odds ratio $(O R)=1.44,95 \%$ confidence interval (CI): 0.99-2.09]. The risk for transport equipment operation, a job with WBV exposure, was significantly elevated $(O R=1.90,95 \%$ CI: 1.07-3.39). These results, together with those of an earlier study, suggest that workers in heavy equipment and transport equipment operation may have increased risk of prostate cancer. Further investigation is warranted.
\end{abstract}

Keywords: cancer epidemiology; retrospective exposure assessment; vibration

\section{INTRODUCTION}

Prostate cancer is the most common cancer among Canadian men, with an estimated 25500 diagnoses

*Author to whom correspondence should be addressed. Tel: (416)-971-9800 ext. 3251; fax: (416)-971-7554; e-mail: Victoria.nadalin@cancercare.on.ca and 4100 deaths in 2011 (Canadian Cancer Society's Steering Committee, 2011). While there are a number of associated risk factors, including age, race and ethnicity, genetics, androgens, and lifestyle (Chen et al., 2009; Crawford, 2009; Patel and Klein, 2009), substantial gaps remain in our understanding of prostate cancer etiology. Other exposures that 
have been explored include pesticides (Dich and Wiklund, 1998; Alavanja et al., 2003; Boers et al., 2005; Mink et al., 2008; Band et al., 2011), cadmium (van der Gulden et al., 1995; Huff et al., 2007; Vinceti et al., 2007; Chen et al., 2009), lubricating oils (Tolbert et al., 1992; Aronson et al., 1996), polycyclic aromatic hydrocarbons (PAH) (Aronson et al., 1996; Boers et al., 2005; Krishnadasan et al., 2007), physical inactivity (Orsini et al., 2009; Pan and DesMeules, 2009), and various occupations (Parent and Siemiatycki, 2001; Zeegers et al., 2004; Pukkala et al., 2009). The collective results of these investigations have been mixed.

Up to $7 \%$ of workers are exposed to whole-body vibration (WBV), which occurs when mechanical energy is transmitted to the body from vibrating surfaces, either through the feet (if standing) or through the trunk (if seated) (Comite Europeen de Normalisation, 1996). WBV is known to cause discomfort, injury, disease, and can interfere with activities (Griffin, 2004). Operators of industrial vehicles, such as crane and loader operators, helicopter pilots, and forklift and tractor drivers, are commonly exposed to WBV (Bovenzi and Hulshof, 1999). While some studies have found an association between prostate cancer and occupations involving heavy vehicle operation, the relationship is typically attributed to PAH exposure (Seidler et al., 1998). A recent case-control study reported a significant association between prostate cancer risk and heavy equipment operation, transportation equipment operation, and working as a trade helper (Sass-Kortsak et al., 2007), which was unrelated to PAH.

Prostate abnormalities such as prostatitis, a risk factor for prostate cancer, have been associated with occupations with WBV exposure (NIOSH, 1974; Sass-Kortsak et al., 2007); furthermore, testosterone level, a possible prostate cancer risk factor, increases with exposure to WBV (Bosco et al., 2000). A systematic review and meta-analysis of prostate cancer and driving occupations with WBV reported a nonsignificant weak association. These authors concluded that there is a need for further study to clarify the role of WBV in prostate cancer etiology (Young et al., 2009). To our knowledge, no other published reports have explored the relationship between WBV and prostate cancer.

Given the high incidence of prostate cancer, widespread exposure to WBV, lack of epidemiological investigation into the association, and suggestive data, it is important to examine $\mathrm{WBV}$ and prostate cancer risk. If WBV increases the risk of prostate cancer, a new avenue for prevention would become available.

\section{METHODS}

Data used in this study are those from a populationbased case-control study, undertaken in Montreal, Quebec, to examine the association between various occupational exposures and a number of cancers, including prostate (Siemiatycki et al., 1981). The study design and data collection methods have been described elsewhere (Siemiatycki et al., 1981). Briefly, cases were males, 35-70 years old, diagnosed with a new histologically confirmed case of 1 of 19 cancer types, ascertained from large hospitals in the Montreal area. Between 1979 and 1985, 4576 eligible cancer cases were ascertained and 3730 personal interviews (mostly in-person) were completed. The participation of large hospitals ensured virtually complete $(97 \%)$ case ascertainment. During this time, 740 population controls were selected by random digit dialling and from electoral lists. Of these, 532 controls completed interviews ( $72 \%$ response rate).

Of 553 eligible prostate cancer cases, 452 cases were interviewed (81.7\% response). Of these, 447 prostate cancer cases provided sufficient data for this analysis. To assess the likelihood of non-response bias, the similarity between respondents and nonrespondents was examined, and only small differences were found. For cases who were unable to respond for themselves (too ill and deceased) or for controls not responding for themselves (illness and lack of interest) next-of-kin, usually spouses, served as proxy respondents.

The two-part questionnaire involved a semistructured section, which asked about potential confounders (e.g. age, ethnic group, height and weight, residential history, schooling, home environment, socio-economic status, hobbies, and consumption of cigarettes and alcohol), and a semi-structured section, which asked for detailed descriptions of each job held. Interviewers asked about company activities, raw materials used, final product, type of machines used, and individual responsibility for machine maintenance. With these detailed job histories, a team of trained industrial hygienists and chemists developed occupational exposure histories. The validity of these job histories has been assessed previously (Baumgarten et al., 1983).

A team of experts (led by A.S.) used the interview data to estimate exposure to WBV for each job held by each participant, blind to case-control status. A total of 4564 jobs were coded for vibration intensity and daily duration of exposure. Using vibration measurement data obtained from a German internet database published by the Brandenburg State Office for Workplace Safety (http://www.las-bb.de/karla), 
from published measurements in the scientific literature, and from their own measurements in the mining and construction operations, a database was constructed to link typical exposure intensities with operation of various types of equipment used, jobs, and industry sector. Industry sectors included agriculture, construction, forestry, manufacturing, military, mining, municipal, and transportation. For each type of equipment used and for each industry sector, mean, standard deviation, and range values were estimated. This database was used by two assessors to assign exposure values to jobs held by participants.

Based on the Gerin et al. (1985) coding structure for chemical exposure that was used in the original study, two semi-quantitative determinants of exposure were assigned:

Intensity of exposure: referred to the average WBV exposure level during the exposure period, using a four-point scale $(0=$ no measureable exposure, $1=\leq 0.45 \mathrm{~m} \mathrm{~s}^{-2}, 2=>0.45-0.945 \mathrm{~m} \mathrm{~s}^{-2}$, and $3=>0.945 \mathrm{~m} \mathrm{~s}^{-2}$ ). Using the questionnaire information on jobs, tasks, and equipment operated, the exposure database was consulted to determine the appropriate exposure intensity code.

Daily duration of exposure: referred to the proportion of time at work exposed to WBV on a scale of $1-3(1=<10 \%, 2=10 \%-30 \%$, and $3=>30 \%)$.

Years of exposure: referred to the total number of years spent in each job with WBV exposure.

Intensity of exposure, daily duration of exposure, and years of exposure were combined in various ways to create new variables that were used to rank exposures. The description of these variables can be found in Table 1.

Exposure assessment procedures were designed to maximize the validity of coding, consistency, and efficiency. Each job was assigned a three-digit industry code (from the Standard Industrial Classification Manual 1970, by the Canadian Federal Department of Statistics) and a seven-digit occupation code (from the Canadian Classification and Dictionary of Occupations 1971, by the Canadian Federal Department of Manpower and Immigration). For each job, intensity and daily duration values were assigned by two raters using a common approach. The rating system was developed in the following manner: (i) the raters first met to agree on an approach to assigning exposure intensity and daily duration; (ii) there was a practice trial of 49 randomly selected participants, where raters assigned intensity and duration codes to the longest job held; (iii) rating disagreements were discussed by raters and consensus was reached; (iv) in a few cases where consensus could not be reached, the
Table 1. Variables explored individually in models used to explore confounding.

\begin{tabular}{|c|c|}
\hline Variable types explored & Individual variables \\
\hline \multirow{3}{*}{$\begin{array}{l}\text { Duration of } \\
\text { exposure measures }\end{array}$} & Daily duration of exposure \\
\hline & $\begin{array}{l}\text { Years in an occupation with high } \\
\text { duration of exposure } \\
\text { (versus the rest) }^{\mathrm{a}}\end{array}$ \\
\hline & $\begin{array}{l}\text { Years in an occupation with mid } \\
\text { or high duration of exposure } \\
\text { (versus the rest) }^{\mathrm{b}}\end{array}$ \\
\hline \multirow{6}{*}{$\begin{array}{l}\text { Intensity of } \\
\text { exposure measures }\end{array}$} & Exposure intensity \\
\hline & $\begin{array}{l}\text { Exposure intensity multiplied by } \\
\text { daily exposure duration }\end{array}$ \\
\hline & $\begin{array}{l}\text { Exposure intensity multiplied by } \\
\text { daily duration of exposure squarec }\end{array}$ \\
\hline & $\begin{array}{l}\text { Exposure intensity by years in } \\
\text { longest job held }\end{array}$ \\
\hline & $\begin{array}{l}\text { Square of exposure intensity } \\
\text { multiplied by years in longest } \\
\text { job held }\end{array}$ \\
\hline & $\begin{array}{l}\text { Square of exposure intensity } \\
\text { by total years }\end{array}$ \\
\hline \multirow[t]{4}{*}{ Occupation categories } & $\begin{array}{l}\text { Blue-collar occupations } \\
\text { (versus white collar) }\end{array}$ \\
\hline & $\begin{array}{l}\text { Occupations with known } \\
\text { WBV exposure (versus the rest) }\end{array}$ \\
\hline & $\begin{array}{l}\text { SOC categories (occupations } \\
\text { grouped by activity) }\end{array}$ \\
\hline & $\begin{array}{l}\text { SIC categories (occupations } \\
\text { grouped by tasks completed) }\end{array}$ \\
\hline
\end{tabular}

${ }^{\text {a }}$ This variable was created by adding up the number of years spent in a high duration of WBV job and creating categories based on the control distribution.

${ }^{\mathrm{b}}$ This variable was created by adding up the number of years spent in a mid or high duration of WBV job and creating categories based on the control distribution.

opinion of A.S. or the research team was sought; (v) trials of inter-rater agreement were then conducted between WBV assessors, using a small sample of questionnaire data; and (vi) degree of agreement in the trials was assessed by overall percentage of agreement and by the $\kappa$ statistic.

Logistic regression analyses were carried out using SAS statistical software, version 9.1 (2004). In total, 979 participants were included, 128 of whom were proxy respondents. There were 447 cases and 532 controls (61 case and 67 control proxies). When added to the model containing the main effects, the interaction term for proxy status and dichotomous exposure was not significant $(P=0.14)$; therefore, proxies were retained.

To explore the data for confounding, each of the variables listed in Table 2 were individually added to a model containing age (continuous) and checked for $a \geq 10 \%$ change in the point estimate for prostate cancer. A number of variables were explored individually, 
Table 2. Variables explored for confounding.

\begin{tabular}{|c|c|}
\hline Variable type & $\begin{array}{l}\text { Individual variables } \\
\text { (added to a model with age) }\end{array}$ \\
\hline \multirow[t]{6}{*}{$\begin{array}{l}\text { Demographic } \\
\text { and personal }\end{array}$} & $\begin{array}{l}\text { Alcohol: number of drinks } \\
\text { consumed in lifetime }\end{array}$ \\
\hline & $\begin{array}{l}\text { Body mass index (a body fat } \\
\text { measure based on height and weight) } \\
<20,20-24.9,25-29.9 \text {, and } \geq 30\end{array}$ \\
\hline & $\begin{array}{l}\text { Education: } 8 \text { or fewer years, } \\
9-12 \text { years, } 13-17 \text { years, } \geq 18 \text { years }\end{array}$ \\
\hline & $\begin{array}{l}\text { Ethnic group: French, Anglo, } \\
\text { Italian, Jewish, Other European, } \\
\text { and other }\end{array}$ \\
\hline & $\begin{array}{l}\text { Income, in Canadian dollars } \\
\text { (based on the mean income of } \\
1981 \text { census): }<20000,20 \text { to } \\
<25000,25 \text { to }<30000, \\
\text { and } \geq 30000\end{array}$ \\
\hline & $\begin{array}{l}\text { Physical activity: lifetime } \\
\text { average at workplace }^{\mathrm{a}}\end{array}$ \\
\hline \multirow{8}{*}{$\begin{array}{l}\text { Occupational } \\
\text { exposure variables }\end{array}$} & Any PAH source \\
\hline & Benzo(a)pyrene exposure \\
\hline & Coal (PAH) \\
\hline & Diesel engine emission exposure \\
\hline & Pesticide exposure \\
\hline & Petroleum (PAH) \\
\hline & Wood (PAH) \\
\hline & Other PAH sources \\
\hline \multirow[t]{2}{*}{ Smoking } & Ever/never \\
\hline & $\begin{array}{l}\text { Number of cigarettes } \\
\text { smoked in lifetime }\end{array}$ \\
\hline
\end{tabular}

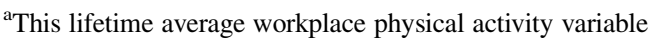
was calculated by (i) multiplying the physical activity level (where $1=\geq 75 \%$ of time sedentary, $2=<75 \%$ sedentary of very active, and $3=\geq 75 \%$ active) for each job by the number of years it was held (ii) adding together each of these values (for each job) for each individual, and then (iii) dividing this value by the total number of years the individual worked.

in each of the same models defined above. That is, age (continuous), along with each of the confounders listed in Table 2, one at a time, with each of the variables listed in Table 1 were added and then removed from the model individually, in order to explore where the confounders were having their primary effect.

Categories of Standard Occupational Code (SOC) and Standard Industrial Code (SIC) were recoded into larger related groupings due to categories with small numbers of respondents. The variables (i) occupations known to have WBV exposure (e.g. transportation, mining, and farming) and (ii) bluecollar/white-collar professions were created by recoding the SOC variable.

Some variables, including pesticide exposure and ethnicity, confounded in only one model, or without consistency, among a range of levels (data not shown). Variables that changed the baseline odds
Table 3. Inter-rater agreement, intensity, and duration of WBV exposure: data collected in English $(n=50)$ and data translated from French $(n=50)$.

\begin{tabular}{lll}
\hline & \multicolumn{2}{l}{ Kappa statistics } \\
\cline { 2 - 3 } & Intensity & Duration \\
\hline Data collected in English & 0.84 & 0.87 \\
$\begin{array}{l}\text { English translation of } \\
\text { data collected in French }\end{array}$ & 0.94 & 0.83 \\
\hline
\end{tabular}

Table 4. Selected demographic characteristics of sample, Montreal, Canada, 1979-1985.

\begin{tabular}{lll}
\hline Characteristic & $\begin{array}{l}\text { Prostate cancer } \\
\text { cases } \\
(n=447)\end{array}$ & $\begin{array}{l}\text { Prostate cancer } \\
\text { controls } \\
(n=532)\end{array}$ \\
\hline $\begin{array}{l}\text { Mean age (range) } \\
\text { Mean of average }\end{array}$ & $\begin{array}{l}2.9(1.5-7.8) \\
\text { lifetime workplace } \\
\text { physical activity }{ }^{\mathrm{a}} \text { (range) }\end{array}$ & $3.0(1.0-7.9)$ \\
Self-administered & & \\
questionnaire & & \\
$\quad$ Yes & 11.0 & 4.0 \\
$\quad$ No & 89.0 & 96.1 \\
BMI (\%) & & \\
$<20$ (underweight) & 3.1 & 3.0 \\
20-24.9 (normal) & 34.2 & 37.0 \\
25-29.9 (overweight) & 42.7 & 46.2 \\
$>29.9$ (obese) & 8.1 & 9.2 \\
Missing & 11.9 & 4.5 \\
PAH exposure (\%) & & 28.8 \\
Unexposed & 30.4 & 71.2 \\
Exposed & 69.6 &
\end{tabular}

${ }^{\mathrm{a}} \mathrm{A}$ description of this variable found in Table 1 .

${ }^{\mathrm{b}}$ There were 77 missing values for BMI. Seventy of these respondents completed a short questionnaire that did not ask for the information needed to calculate BMI.

ratio (OR) estimates (by $\geq 10 \%$ ) in more than one model and in more than one level (of a multilevel variable) were retained in the final models.

\section{RESULTS}

The inter-rater agreement for intensity and duration of WBV exposure in a selection of jobs pre-consensus was good ( $\kappa=0.78$ and 0.69 for intensity and duration, respectively) and improved substantially in the post-consesus trial for both data collected in English $(n=50)$ and data collected in French $(n=50)$. The agreement between the two expert raters on intensity and duration of WBV exposure in a selection of jobs is summarized in Table 3. As can be seen by the $\kappa$ statistics, there was very good agreement between the two raters for both variables and both types of data. 
Selected characteristics of prostate cancer cases and controls are shown in Table 4. Controls were younger, had slightly higher levels of average lifetime workplace physical activity, and were more likely to have been exposed to PAH in their workplace. Controls also were much less likely to have completed a self-administered questionnaire (as opposed to an interview).

The model of intensity of exposure (with age) was confounded by average lifetime workplace physical activity, although the direction was inconsistent and the point estimates were not statistically significant (data not shown). Explorations of SOC indicated confounding for a number of occupations when average workplace physical activity and then body mass index were added to the models; however, the categories had small numbers of respondents, and the point estimates were not statistically significant. Associations for SIC, jobs known to have WBV exposure (except when average workplace physical activity was added to the model), blue-collar occupation, and number of years in occupations with varying durations of exposure did not produce results of statistical significance (data not shown).

The multivariate model is shown in Table 5. While a number of occupations demonstrate an increased risk, only the fully adjusted OR for transport equipment operators (e.g. air, water, rail, motor transport) showed a statistically significant increased risk [OR $=1.90$, 95\% confidence interval (CI): 1.07-3.39]. While occupations with exposure to WBV show increased risk, these estimates (age and fully adjusted) did not reach statistical significance. Looking at intensity, duration, and total years of exposure, a non-statistically significant U-shaped distribution was observed, with those at a medium level of exposure showing a higher age-adjusted OR (1.14) than those at the highest level of exposure (1.04).

\section{DISCUSSION}

Evidence suggests that driving occupations and exposure to diesel fumes are associated with prostate cancer (Minder and Beer-Porizek, 1992; Seidler et al., 1998). Although a recent study of occupational factors and prostate cancer (Sass-Kortsak et al., 2007) found no association with exposure to various chemicals, such as PAH, diesel fume, metals, and pesticides, a significant positive association was found for work in trades, transport, and equipment operators, based on the longest held occupation. In this occupational category, the significant association, unrelated to $\mathrm{PAH}$ exposure, was confined to the subcategories: heavy equipment operators, transport equipment operators and trades helpers, and construction and transportation laborers $(\mathrm{OR}=$ 1.21, 95\% CI: 1.01-1.46). Post hoc, it was theorized that WBV may have contributed to an elevated risk for trades, transport, and equipment operators. When jobs unlikely to have WBV exposure were excluded, the OR increased (OR $=1.38,95 \%$ CI: $1.07-1.78)$.

While the present study used an earlier version of SOC codes than that used by Sass-Kortsak et al. (2007), both studies found an association between jobs with probable WBV exposure (heavy and transport equipment operation) and prostate cancer after adjustment for various confounders. Sass-Kortsak et al. (2007), using participants residing in a relatively rural area (northern Ontario), had findings similar to those reported in this paper, which are

Table 5. Measures of WBV and risk of prostate cancer, Montreal, Canada, 1979-1985. Fully adjusted.

\begin{tabular}{lllll}
\hline Variable & Levels $(N)$ & $\begin{array}{l}\text { Age-adjusted } \\
\text { OR }(95 \% \text { CI })\end{array}$ & $\begin{array}{l}\text { Multivariate } \\
\text { OR }(95 \% \text { CI })^{\mathrm{a}}\end{array}$ & $\begin{array}{l}P \text { value, } \\
\text { main effect }\end{array}$ \\
\hline $\begin{array}{l}\text { Intensity by duration } \\
\text { by years, summed }\end{array}$ & No exposure ${ }^{\mathrm{b}}(488)$ & 1.00 & 1.00 & 0.3809 \\
& $<33(240)$ & $1.14(0.82-1.57)$ & $1.26(0.89-1.79)$ \\
Occupation known & $33-726(251)$ & $1.04(0.76-1.43)$ & $1.19(0.84-1.69)$ \\
for WBV & No exposure (823) & 1.00 & 1.00 & 0.0584 \\
SOC (recoded) & Exposure (156) & $1.29(0.90-1.84)$ & $1.44(0.99-2.09)$ \\
& $1=$ white collar (422) & 1.00 & 1.00 & 0.3288 \\
& $2=$ protective service, etc. (23) & $0.93(0.40-2.20)$ & $1.29(0.53-3.16)$ \\
& $3=$ processing and machining (276) & $1.04(0.76-1.43)$ & $1.43(0.96-2.12)$ \\
& $4=$ farming, forestry, etc. (38) & $1.03(0.52-2.03)$ & $1.64(0.74-3.61)$ \\
& $5=$ construction and trades $(112)$ & $1.03(0.66-1.59)$ & $1.62(0.93-2.81)$ \\
& $6=$ transport equipment operation (74) & $1.41(0.84-2.36)$ & $1.90(1.07-3.39)$ \\
& $7=$ material handling (32) & $1.31(0.62-2.77)$ & $1.88(0.84-4.23)$ \\
\hline
\end{tabular}

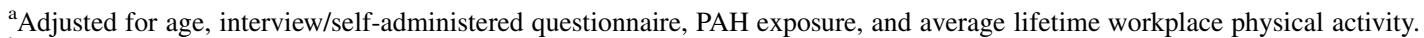

${ }^{\mathrm{b}}$ Note: half of the respondents ( $52 \%$ of controls and $48 \%$ of cases) were not exposed to WBV.
} 
based on the responses of residents in and around a large metropolitan centre in Quebec. This present analysis found that only jobs involving the operation of transport equipment were associated with a significantly elevated risk of prostate cancer $(\mathrm{OR}=1.90$, 95\% CI: 1.07-3.39), which suggests that aspects of heavy equipment driving occupations are linked to prostate cancer. Both studies found no association between the disease outcome and PAH exposure. While driving occupations are often sedentary, no relationship between prostate cancer risk and workplace physical activity was found in these studies.

There are a number of limitations to this study. While the assessments of exposure to WBV intensity and daily duration had good inter-rater reliability, misclassification is still possible. The WBV levels for a number of machines were based on a small sample sizes; therefore, we cannot be certain that the values for a particular machine represent WBV levels for all similar machines. Also, most of the measurement data in this study were collected over the past two decades, not necessarily reflective of similar machines and operations in earlier decades, when most of the participants were employed. Advances in equipment design, particularly in relation to seats, have dramatically lowered WBV levels. As these improvements have been across most industry sectors, it is possible that the relative rankings of WBV exposure by equipment remained more or less the same; however, this is an area of uncertainty. Furthermore, driving terrain, an important driver of vibration, is not assessed in this study.

The relatively small number of participants exposed to WBV is also a limitation, as is the unavailability of vibration frequency data. Health effects likely occur only at or close to a vibration resonance frequency of the prostate gland; the vibration frequency experienced by participants was not available for the assessors. Another limitation on this study is limited precision in WBV exposure estimates (which were based on self-reported job histories), recall bias is possible, jobs and equipment change over time, and there is variability in exposure within each job/equipment type.

This study examined a number of derived exposure variables, incorporating measures of intensity, daily exposure, and years of exposure in each job. None of the derived variables was associated with prostate cancer, and there was no evidence of a dose-response relationship. Thus, it is possible that there is no link between WBV and prostate cancer, and the increased risk in heavy and transport equipment operation is due to some other factor. However, more precise measures of WBV may be required.

\section{CONCLUSIONS}

The significant association between prostate cancer and operation of heavy equipment and transport equipment found in this, and in a second independent cohort, suggests that workers in these sectors may be at risk. Further investigation is warranted and should include WBV exposure assessment, using these and other measures of exposure, such as vibration dose values, and also accounting for vibration frequency.

\section{FUNDING}

Workplace Safety and Insurance Board (Ontario).

\section{REFERENCES}

Alavanja MC, Samanic C, Dosemeci M et al. (2003) Use of agricultural pesticides and prostate cancer risk in the agricultural health study cohort. Am J Epidemiol; 157: 800-14.

Aronson KJ, Siemiatycki J, Dewar R et al. (1996) Occupational risk factors for prostate cancer: results from a case-control study in Montreal, Quebec, Canada. Am J Epidemiol; 143: 363-73.

Band PR, Abanto Z, Bert J et al. (2011) Prostate cancer risk and exposure to pesticides in British Columbia farmers. Prostate; 71: 168-83.

Baumgarten M, Siemiatycki J, Gibbs GW. (1983) Validity of work histories obtained by interview for epidemiologic purposes. Am J Epidemiol; 118: 583-91.

Boers D, Zeegers MP, Swaen GM et al. (2005) The influence of occupational exposure to pesticides, polycyclic aromatic hydrocarbons, diesel exhaust, metal dust, metal fumes, and mineral oil on prostate cancer: a prospective cohort study. Occup Environ Med; 62: 531-7.

Bosco C, Iacovelli M, Tsarpela O et al. (2000) Hormonal responses to whole-body vibration in men. Eur J Appl Physiol; 81: 449-54.

Bovenzi M, Hulshof CT. (1999) An updated review of epidemiologic studies on the relationship between exposure to whole-body vibration and low back pain (1986-1997). Int Arch Occup Environ Health; 72: 351-65.

Canadian Cancer Society's Steering Committee. (2011) Canadian cancer statistics 2011. Toronto, Canada: Canadian Cancer Society.

CEN. (1996) Mechanical vibration - guide to the health effects of vibration on the human body. Brussels, Belgium: Comite Europeen de Normalisation. pp. 12349.

Chen YC, Pu YS, Wu HC et al. (2009) Cadmium burden and the risk and phenotype of prostate cancer. BMC Cancer; 9: 429.

Crawford ED. (2009) Understanding the epidemiology, natural history, and key pathways involved in prostate cancer. Urology; 73 (5 Suppl): S4-10.

Dich J, Wiklund K. (1998) Prostate cancer in pesticide applicators in Swedish agriculture. Prostate; 34: 100-12.

Gerin M, Siemiatycki J, Kemper H et al. (1985) Obtaining occupational exposure histories in epidemiologic case-control studies. J Occup Med; 27: 420-6.

Griffin MJ. (2004) Minimum health and safety requirements for workers exposed to hand-transmitted vibration and 
whole-body vibration in the European Union: a review. Occup Environ Med; 61: 387-97.

Huff J, Lunn RM, Waalkes MP et al. (2007) Cadmium-induced cancers in animals and in humans. Int $\mathrm{J}$ Occup Environ Health; 13: 202-12.

Krishnadasan A, Kennedy N, Zhao Y et al. (2007) Nested casecontrol study of occupational chemical exposures and prostate cancer in aerospace and radiation workers. Am J Ind Med; 50: 383-90.

Minder CE, Beer-Porizek V. (1992) Cancer mortality of Swiss men by occupation, 1979-1982. Scand J Work Environ Health; 18 (3 Suppl): 1-27.

Mink PJ, Adami HO, Trichopoulos D et al. (2008) Pesticides and prostate cancer: a review of epidemiologic studies with specific agricultural exposure information. Eur $\mathrm{J}$ Cancer Prev; 17: 97-110.

NIOSH. (1974) Relationship between whole-body vibration and morbidity patterns among heavy equipment operators. Cincinnati, OH: National Institue of Occupational Safety and Health, DHHS (NIOSH) Publication\# 74-131, NIOSH.

Orsini N, Bellocco R, Bottai M et al. (2009) A prospective study of lifetime physical activity and prostate cancer incidence and mortality. Br J Cancer; 101: 1932-8.

Pan SY, DesMeules M. (2009) Energy intake, physical activity, energy balance, and cancer: epidemiologic evidence. Methods Mol Biol; 472: 191-215.

Parent ME, Siemiatycki J. (2001) Occupation and prostate cancer. Epidemiol Rev; 23: 138-43.
Patel AR, Klein EA. (2009) Risk factors for prostate cancer. Nature Clinical Practice. Urology; 6: 87-95.

Pukkala E, Martinsen JI, Lynge E et al. (2009) Occupation and cancer-follow-up of 15 million people in five Nordic countries. Acta Oncol; 48: 646-790.

Sass-Kortsak AM, Purdham JT, Kreiger N et al. (2007) Occupational risk factors for prostate cancer. Am J Ind Med; 50: 568-76.

Seidler A, Heiskel H, Bickeboller R et al. (1998) Association between diesel exposure at work and prostate cancer. Scand J Work Environ Health; 24: 486-94.

Siemiatycki J, Day NE, Fabry J et al. (1981) Discovering carcinogens in the occupational environment: a novel epidemiologic approach. J Natl Cancer Inst; 66: 217-25.

Tolbert PE, Eisen EA, Pothier LJ et al. (1992) Mortality studies of machining-fluid exposure in the automobile industry II. Risks associated with specific fluid types. Scand J Work Environ Health; 18: 351-60.

van der Gulden JW, Kolk JJ, Verbeek AL. (1995) Work environment and prostate cancer risk. Prostate; 27: 250-7.

Vinceti M, Venturelli M, Sighinolfi C et al. (2007) Casecontrol study of toenail cadmium and prostate cancer risk in Italy. Sci Total Environ; 373: 77-81.

Young E, Kreiger N, Purdham J et al. (2009) Prostate cancer and driving occupations: could whole body vibration play a role? Int Arch Occup Environ Health; 82: 551-6.

Zeegers MP, Friesema IH, Goldbohm RA et al. (2004) A prospective study of occupation and prostate cancer risk. J Occup Environ Med; 46: 271-9. 